\title{
The clinical effects of somatotype difference on isokinetic knee muscle strength and dynamic balance scores
}

\author{
Deniz Şenol, ${ }^{1}$ Davut Özbağ, ${ }^{1}$ Muhammed Emin Kafkas, ${ }^{2}$ Mahmut Açak, ${ }^{2}$ Özlem Baysal, ${ }^{3}$ Armağan Şahin Kafkas, ${ }^{2}$ \\ Celal Taşkıran, ${ }^{2}$ Mahmut Çay, ${ }^{1}$ Derya Yağar, ${ }^{4}$ Gökmen Özen ${ }^{2}$ \\ 'Department of Anatomy, Inonu University Faculty of Medicine, Malatya, Turkey \\ ${ }^{2}$ İnönü University, School of Physical Education and Sports, Malatya, Turkey \\ ${ }^{3}$ Department of Physical Medicine and Rehabilitation, Inonu University Faculty of Medicine, Malatya, Turkey \\ ${ }_{4}^{4}$ Department of Physical Medicine and Rehabilitation, Malatya State Hospital, Malatya, Turkey
}

Received: September 27, 2016 Accepted: November 18, 2016 Published online: March 21, 2017

\begin{abstract}
Objectives: The aim of this study was to present the somatotype features of young individuals without any symptoms and to identify whether isokinetic knee muscle strength and dynamic balance scores are affected by somatotype difference.

Patients and methods: A total of 146 participants ( 88 males, 58 females; mean age $22.5 \pm 1.9$ years; range 19 to 28 years) who had no symptoms were included in this study. Somatotypes of the participants were calculated using the Heath-Carter formula, and anthropometric measurements were taken from each participant. Knee flexion and extension muscle strengths at angular speeds of $90 \% \mathrm{sec}, 120 \% \mathrm{sec}$ and $150 \%$ sec were measured from the dominant and non-dominant limbs of the participants. Total balance, anterior/posterior balance, and medial/ lateral measurements were made to evaluate dynamic balance performances.

Results: Six different somatotypes were found. Endomorphic mesomorph was the most common somatotype in 56 participants. There was no significant somatotype difference in men and women for dominant and non-dominant knee extension and flexion peak strength values at angular speeds of $90 \% \mathrm{sec}, 120 \% \mathrm{sec}$ and $150 \% \mathrm{sec}(\mathrm{p}>0.05)$. No significant difference was found between the balance scores of men and women who had different somatotypes ( $\mathrm{p}>0.05)$.
\end{abstract}

Conclusion: Anatomic structure of the body, which is suitable for the sports branch, has an increasing effect on performance.

Keywords: Anthropometry; dynamic balance; isokinetic strength; somatotype.

Identifying the isokinetic strength profiles of athletes with different somatotypes and different branches is critical in terms of performing the necessities of the branch and in terms of the continuity of athletes' top level performance. ${ }^{[1,2]}$ Isokinetic dynamometers are the most useful method in identifying muscle balance and strength between dominant/non-dominant and agonist/antagonist. ${ }^{[2,3]}$ An accurate assessment of the muscle strength of athletes plays an important role in making suitable training programs, increasing performance, preventing injuries which result from athletes' weakness and finding suitable programs to treat injuries. ${ }^{[2,4,5]}$ The integration of information from sensory systems informs one about his orientation to maintain posture control in space which allows regulatory reflexive actions. ${ }^{[6]}$ However, sensory inputs alone are not responsible for continuing postural control. Postural stability depends on numerous neural pathways for the effectiveness of systems within central nervous system and motor control. ${ }^{[7]}$ Peripheral components on balance include somatosensorial, visual and vestibular systems. Central nervous system combines the peripheral data from these systems and selects a great number of suitable muscular responses to control posture on body composition and support

Corresponding author: Deniz Şenol, MD. İnönü Üniversitesi Tıp Fakültesi Anatomi Anabilim Dalı, 44280 Malatya, Turkey. e-mail: deniz.senol@inonu.edu.tr 
base. Balance forms a basis for a good performance and is defined as transmitter within the nervous system. A person's ability in securing balance can be defined as a determining factor in developing other motor systems. Maintaining balance and a stable posture is known as an indispensable part of a great number of movement practices. Control and maintenance of balance is a complex motor ability which includes planning and practicing flexible courses of action as well as integrating sensory input. ${ }^{[8]}$

Performance is the score put forward physically, physiologically, biomotorically and psychomentally by individuals and athletes. The main goals of the science of training are to maximize performance and to maintain top level performance limits. Studies on determining the specific strength, speed, endurance, and flexibility features of sports branches which is among the factors in reaching high performance levels are on the increase. Recently, correct athlete choice and correct training programs have been shown as the most important factors on the basis of records broken in many sport branches and the success accomplished. ${ }^{[9]}$ It is an undeniable fact that in our daily lives, or more specifically in sports, competition is dependent on having suitable somatotype, body composition and anthropometric measures.

Our hypothesis at the beginning of this study was that different somatotypes would have an effect on isokinetic muscle strength and dynamic balance scores. Literature review has shown that a great number of studies have been conducted on somatotype difference. It was found that these studies assessed different age groups and the assessments were made with only three main somatotype classifications which consisted of endomorphy, mesomorphy and ectomorphy. Different from previous studies, the examinations were made with 13 subgroups of three main somatotype classifications and six subgroups which were found were assessed. Another aim of the study was to find out the association between isokinetic knee muscle strength and dynamic balance in different somatotypes. Such a detailed examination has not been conducted in any of the previous studies and the association between somatotype features and the tests which find out isokinetic muscle strength and dynamic balance scores have been assessed in this study for the first time to contribute to the literature.

\section{PATIENTS AND METHODS}

This study was conducted with the 2014/55 numbered permission of Malatya Clinical Researches Ethical Board. A written informed consent was obtained from each participant. The study was conducted in accordance with the principles of the Declaration of Helsinki.

A total of 146 participants (88 males, 58 females; mean age $22.5 \pm 1.9$ years; range 19 to 28 years) who had no symptoms were included in this study. All participants who were studying at Inonu University, School of Physical Training and Sports (PTSS) and who did not have a training system were included on a voluntary basis. The inclusion criteria were as follows: (i) having a physically healthy appearance, (ii) not having any medical obstacles to participate in the study or not using any medication (iii) not using any food supplements to boost performance (such as creatine), (iv) not having any diseases and not having any previous orthopedic surgical operation.

\section{Calculation of somatotypes}

Somatotype (1.2.6 trial) program designed by Heath-Carter formula was used for the calculation of somatotypes and for somatotype drawings. Anthropometric measurements such as height and weight, triceps, subscapular, supraspinale, and calf skinfold thickness (SF), knee and elbow width and arm and calf circumferences were taken from each student in line with the techniques set forth by the International Biological Program (IBP) and International Society for the Advancement of Kinanthropometry (ISAK) to determine somatotype. The SFs were measured by using the baseline skinfold caliper $12-1110 .^{[10,11]}$ Height and knee and elbow widths were measured using the Harpenden anthropometer set (Holtain Ltd., Crymych, Dyfed, Wales, UK). Weights were measured with Tanita body composition analyzer (BC-418 MA) device (Tanita Europe BV, Amsterdam, Netherlands). ${ }^{[12]}$ Arm and calf circumferences were measured using the baseline circumference. ${ }^{[10,11,13]}$

\section{Anthropometric measurements}

Height, the distance between the vertex point of the head and the floor, was measured. Weight, the measurement was made after the participant's shoes, and extra weights were taken off. For the triceps SF, the measurement was taken, when the participant was on foot, hanging his arms freely to the sides without contracting. The measurement was taken over and from the midpoint of the triceps muscles behind the arm. For the subscapular SF, the measurement was taken by removing the skin and the underlying skin layer by complying with the natural folds of the skin, right under the scapulas of the participants and the thumb, index, and middle fingers of the left hand. For 
the supraspinale, the measurement was made, when the participant was standing over the ileum bone and the line on which midaxillary line was. For the calf SF, the measurement was made by removing some skin from the medial area of the leg. For the elbow width, the arm was pulled slightly to the front and the palm of the hand was bent up $90^{\circ}$ from the elbow. The measurement was taken from between the epicondylus lateralis and epicondylus medialis points of the humerus. For the knee width, the distance between the most topped two points of inner and outer sides of articulatio genus was measured. For the arm circumferences, the measurement was taken from the most topped areas of the midpoint between acromion and olecranon. For the calf circumferences, the tape was wrapped vertically to the long axis of the leg at maximum hip thickness and the measurement was taken. ${ }^{[2,10,11]}$

\section{Isokinetic strength and dynamic balance measurements}

Knee flexion and extension muscle strengths of the participants in the study were measured with Biodex System 3 Isokinetic test and Exercise Device (Biodex Inc., Shirley, NY, USA Model: $830-220$ ) at $90 \%$ sec, $120 \% \mathrm{sec}$ and $150 \% \mathrm{sec}$ angular speeds. Dominant and non-dominant limbs of all the participants were tested.
The participants were fixed with a belt in sitting position and the test was started by fixing hands held crosswise from the shoulders. The peak torque values were recorded for each angular speed.

The Biodex Balance Simulator (Model: 945-302) was used to find out dynamic balance performances. After the participants were instructed about the practices in a fixed platform before the test, the test was started. Total balance, anterior/posterior balance and medial/ lateral balance measurements were found as a result of the measurements. ${ }^{[14,15]}$

\section{Statistical analysis}

Statistical analysis was performed using the IBM SPSS version 22.0 software (IBM Corp., Armonk, NY, USA). The normality of the data was analyzed using the Shapiro-Wilk test. The Kruskal-Wallis $\mathrm{H}$ test was used to analyze data. The descriptive data were expressed in median and range (min-max). A $p$ value of $<0.05$ was considered statistically significant.

\section{RESULTS}

Six different somatotypes were determined from 146 participants in the study. Endomorphic mesomorph somatotype was the most common

Table 1. The distribution of somatotypes and median (min-max) values of parameters used in somatotype calculations of male and female participants in the study

\begin{tabular}{lcc}
\hline & \multicolumn{2}{c}{ Distribution of somatotypes } \\
\cline { 2 - 3 } Somatotypes & Male & Female \\
\cline { 2 - 3 } Endomorphic mesomorph (participants) & 48 & 8 \\
Mesomorph endomorph (participants) & 13 & 15 \\
Central (participants) & 9 & 14 \\
Balanced mesomorph (participants) & 18 & - \\
Mesomorphic endomorph (participants) & - & 9 \\
Balanced endomorph (participants) & - & 9
\end{tabular}

\begin{tabular}{|c|c|c|c|c|}
\hline \multirow[b]{3}{*}{ Parameter } & \multicolumn{4}{|c|}{ Parameters used in somatotype calculations } \\
\hline & \multicolumn{2}{|c|}{ Male } & \multicolumn{2}{|c|}{ Female } \\
\hline & Median & Min-Max & Median & $\overline{M i n-M a x}$ \\
\hline Age (year) & 23 & $19-28$ & 21.5 & $19-26$ \\
\hline Height $(\mathrm{cm})$ & 174.2 & $158.5-193$ & 162.5 & $147-179$ \\
\hline Arm circumferences $(\mathrm{cm})$ & 8.5 & $6.6-10.3$ & 7.2 & $5.9-8.4$ \\
\hline Calf circumferences $(\mathrm{cm})$ & 8.8 & $7.8-10.3$ & 8.1 & $6.8-9.8$ \\
\hline Elbow width $(\mathrm{cm})$ & 31 & $25.5-40$ & 27 & $23-33$ \\
\hline Knee width $(\mathrm{cm})$ & 36.5 & $32-42$ & 34 & $28-40$ \\
\hline Mass (kg) & 71.5 & $51.6-93.9$ & 56.2 & $39.8-73.2$ \\
\hline Triceps skinfold thickness $(\mathrm{mm})$ & 11 & $5-24$ & 16 & $2.5-30$ \\
\hline Subscapular skinfold thickness (mm) & 13 & $5-25$ & 12.5 & $4-25$ \\
\hline Supraspinale skinfold thickness $(\mathrm{mm})$ & 14 & $4-36$ & 15 & $3-27$ \\
\hline Calf skinfold thickness $(\mathrm{mm})$ & 12 & $3-25$ & 16 & $3-30$ \\
\hline Endomorphy & 3.9 & $1.7-6.8$ & 4.3 & 3-7.4 \\
\hline Mesomorphy & 5.5 & $2.6-8.2$ & 4 & $2.5-7.1$ \\
\hline Ectomorphy & 2.1 & $0.5-4.4$ & 2.7 & $0.1-4.3$ \\
\hline
\end{tabular}

Min: Minimum; Max: Maximum. 


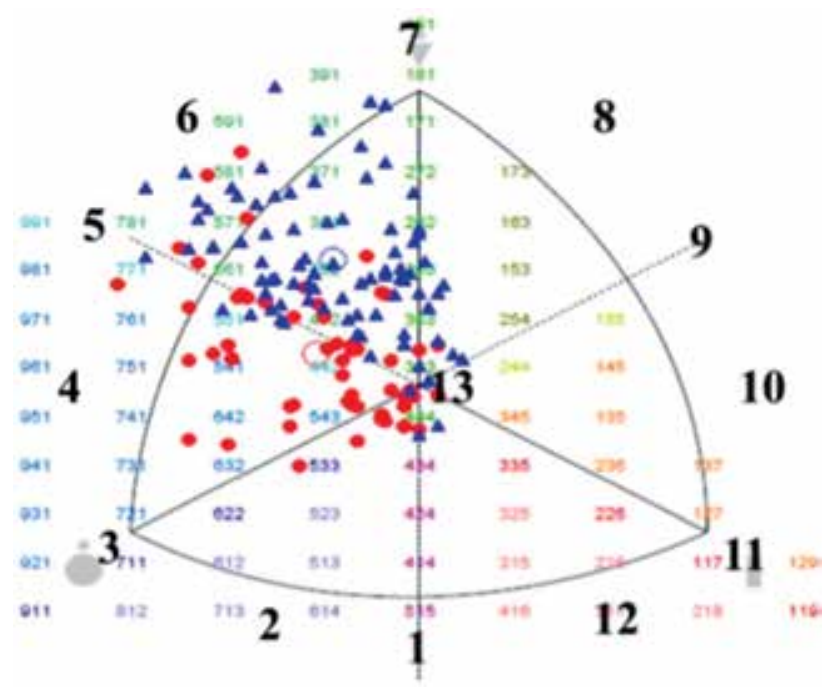

Figure 1. Somatoplot representations of male and female the somatotype characteristics. 1: Endomorph ectomorph; 2: Ectomorphic endomorph; 3: Balanced endomorph; 4: Mesomorphic endomorph; 5: Mesomorph endomorph; 6: Endomorphic mesomorph; 7: Balanced mesomorph; 8: Ectomophic mesomorph; 9: Mesomorph ectomorph; 10: Mesomorphic ectomorph; 11: Balanced ectomorph; 12: Endomorphic ectomorph; 13: Central; O: Mean somatotype; Triangle: Male; Circle: Female.

Table 2. Median (min-max) values of somatotypes at specified angular speeds and Kruskal-Wallis $\mathrm{H}$ test analysis results of knee isokinetic muscle strength $(\mathrm{Nm})$ at different angular speeds and overall, anterior/posterior and medial/lateral dynamic balance scores (sec) in male participants

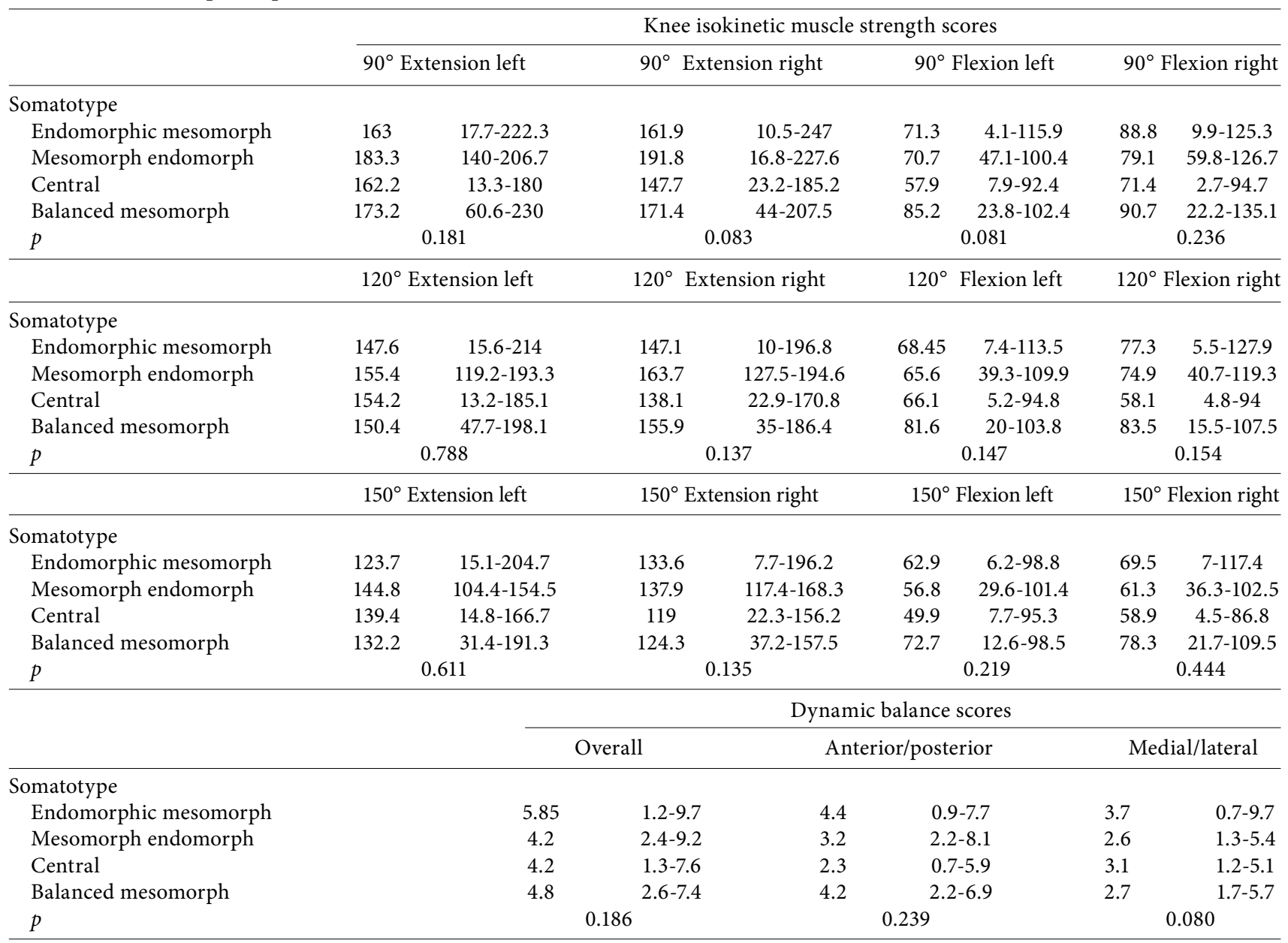


Table 3. Median (min-max values of somatotypes at specified angular speeds and Kruskal-Wallis $\mathrm{H}$ test analysis results of knee isokinetic muscle strength $(\mathrm{Nm})$ at different angular speeds and overall, anterior/posterior and medial/lateral dynamic balance scores (sec) in female participants

\begin{tabular}{|c|c|c|c|c|c|c|c|c|}
\hline & \multicolumn{8}{|c|}{ Knee isokinetic muscle strength scores } \\
\hline & \multicolumn{2}{|c|}{$90^{\circ}$ Extension left } & \multicolumn{2}{|c|}{$90^{\circ}$ Extension right } & \multicolumn{2}{|c|}{$90^{\circ}$ Flexion left } & \multicolumn{2}{|c|}{$90^{\circ}$ Flexion right } \\
\hline \multicolumn{9}{|l|}{ Somatotype } \\
\hline Endomorphic mesomorph & 111.2 & $55.5-149.4$ & 121.3 & $45.8-147.9$ & 44.6 & $20.4-55.7$ & 58.5 & $23.9-68.2$ \\
\hline Mesomorph endomorph & 113.2 & $98.7-160.6$ & 124.5 & $95.5-160.8$ & 53.6 & $22.5-75.3$ & 39.9 & $17.2-74.8$ \\
\hline Central & 104 & $42.9-143.9$ & 116.3 & $61.5-130.9$ & 44.2 & $14-59.2$ & 44.8 & $18.3-62.3$ \\
\hline Mesomorphic endomorph & 111.1 & $52.9-146.1$ & 112.2 & $50.8-129.6$ & 50.1 & $25-79.1$ & 46.5 & $23.1-64.3$ \\
\hline Balanced endomorph & 93.9 & $62.4-122.1$ & 102.7 & $60.2-120.7$ & 35 & $15.1-56.2$ & 44.6 & $27.1-54.1$ \\
\hline \multirow[t]{2}{*}{$p$} & \multicolumn{2}{|c|}{0.202} & \multicolumn{2}{|c|}{0.236} & \multicolumn{2}{|r|}{0.515} & \multicolumn{2}{|r|}{0.093} \\
\hline & \multicolumn{2}{|c|}{$120^{\circ}$ Extension left } & \multicolumn{2}{|c|}{$120^{\circ}$ Extension right } & \multicolumn{2}{|c|}{$120^{\circ}$ Flexion left } & \multicolumn{2}{|c|}{$120^{\circ}$ Flexion right } \\
\hline \multicolumn{9}{|l|}{ Somatotype } \\
\hline Endomorphic mesomorph & 101.3 & $51.2-126$ & 103.3 & $36.8-126.2$ & 42.35 & $15.9-53.5$ & 53 & $13-62.8$ \\
\hline Mesomorph endomorph & 106.3 & $78.9-143.7$ & 104.45 & $75.9-130.1$ & 40.9 & $19.2-69.7$ & 43.4 & $19.1-57.8$ \\
\hline Central & 94.85 & $0-117.5$ & 96.1 & $55.7-113.2$ & 35.9 & $0-51.1$ & 43.7 & $16-55.3$ \\
\hline Mesomorphic endomorph & 95 & $52.3-128$ & 95.2 & $41.8-109$ & 51.1 & $25.7-65.5$ & 44.1 & $16.8-64.3$ \\
\hline Balanced endomorph & 91.4 & $64-109.1$ & 92 & $50.4-106.6$ & 35.7 & $14.6-48.2$ & 44.6 & $22.2-48.3$ \\
\hline \multirow[t]{2}{*}{$p$} & \multicolumn{2}{|c|}{0.705} & \multicolumn{2}{|c|}{0.238} & \multicolumn{2}{|r|}{0.051} & \multicolumn{2}{|r|}{0.186} \\
\hline & \multicolumn{2}{|c|}{$150^{\circ}$ Extension left } & \multicolumn{2}{|c|}{$150^{\circ}$ Extension right } & \multicolumn{2}{|c|}{$150^{\circ}$ Flexion left } & \multicolumn{2}{|c|}{$150^{\circ}$ Flexion right } \\
\hline \multicolumn{9}{|l|}{ Somatotype } \\
\hline Endomorphic mesomorph & 88.8 & $43.7-107.2$ & 85.5 & $32.8-115.8$ & 45 & $16.9-53.4$ & 46.05 & $14.6-59.4$ \\
\hline Mesomorph endomorph & 89.2 & $76-128.3$ & 89 & $67.7-121.3$ & 38.5 & $19.2-61.9$ & 40.4 & $24.7-59.8$ \\
\hline Central & 79.85 & $38.7-107.3$ & 78.2 & $35.9-95.3$ & 33.7 & $17.4-54.6$ & 39.5 & $12.3-52.1$ \\
\hline Mesomorphic endomorph & 79.5 & $37.1-108.6$ & 84.1 & $43.1-102.2$ & 42.2 & $14.3-56.4$ & 42.4 & $19.2-58.6$ \\
\hline Balanced endomorph & 81.5 & $54.2-91.5$ & 77 & $48.1-96.4$ & 36 & $15.6-56.8$ & 35.4 & $24.3-46.3$ \\
\hline \multirow[t]{3}{*}{$p$} & \multicolumn{2}{|c|}{0.368} & & & & 0.626 & & 0.237 \\
\hline & & & & Dynam & palance & scores & & \\
\hline & & & & Ant & or/poste & rior & Med & ial/lateral \\
\hline Somatotype & & & & & & & & \\
\hline Endomorphic mesomorph & & 3.45 & $1.9-7.4$ & 2.55 & & -6.3 & 1.95 & $1.6-4.7$ \\
\hline Mesomorph endomorph & & 5.7 & $1.3-9.3$ & 4.6 & & -7.4 & 2,9 & $1,1-5,8$ \\
\hline Central & & 3.95 & $1.3-11.7$ & 2.85 & & -5.6 & 2.6 & $0.8-10.9$ \\
\hline Mesomorphic endomorph & & 6.45 & $2.2-10$. & 4.8 & & -6.9 & 3.35 & $1.2-10.3$ \\
\hline Balanced endomorph & & 5.1 & $1.9-9.8$ & 3.3 & & -7.7 & 2.6 & $1.6-6.3$ \\
\hline$p$ & & & & & .224 & & & 0.733 \\
\hline
\end{tabular}

somatotype with 56 participants. Mesomorph endomorph somatotype was found in 28 participants, central somatotype was found in 23 participants, balanced mesomorph somatotype was found in 18 participants, mesomorphic endomorph somatotype was found in 12 and balanced endomorph somatotype was found in nine participants.

The median values of males were defined as age 23 , height $174.2 \mathrm{~cm}$, arm circumferences $8.5 \mathrm{~cm}$, calf circumferences $8.8 \mathrm{~cm}$, elbow width $31 \mathrm{~cm}$, knee width $36.5 \mathrm{~cm}$, mass $71.5 \mathrm{~kg}$, triceps SF $11 \mathrm{~mm}$, subscapular SF $13 \mathrm{~mm}$, supraspinale SF $14 \mathrm{~mm}$, and calf SF $12 \mathrm{~mm}$. The median values of male body components were as follows: endomorphy 3.9, mesomorphy 5.5, and ectomorphy 2.1. The median values of females were defined as age 21.5 , height $162.5 \mathrm{~cm}$, arm circumferences $7.2 \mathrm{~cm}$, calf circumferences $8.1 \mathrm{~cm}$, elbow width $27 \mathrm{~cm}$, knee width $34 \mathrm{~cm}$, mass $56.2 \mathrm{~kg}$, triceps SF $16 \mathrm{~mm}$, subscapular SF $12.5 \mathrm{~mm}$, supraspinale SF $15 \mathrm{~mm}$, and calf SF $16 \mathrm{~mm}$. The median values of female body components were as follows: endomorphy 4.3, mesomorphy 4, and ectomorphy 2.7. The distribution, somatoplot representations, mean $\pm S D$, $\min , \max$ values of age, height $(\mathrm{cm})$, arm girth $(\mathrm{cm})$, calf girth $(\mathrm{cm})$, elbow breadth $(\mathrm{cm})$, knee breadth $(\mathrm{cm})$, mass $(\mathrm{kg})$, triceps SF (mm), subscapular SF ( $\mathrm{mm})$, supraspinale SF $(\mathrm{mm})$, calf SF $(\mathrm{mm})$ used in somatotype calculations of male and female participants and endomorphy, mesomorphy, and ectomorphy components found of somatotypes in terms of male and female participants 
are given below (Table 1 and Figure 1).

After the somatotypes of male and female participants were found in the light of the parameters taken, knee isokinetic muscle strength was assessed at angular speeds of $90 \% \mathrm{sec}, 120 \% \mathrm{sec}, 150 \% \mathrm{sec}$ according to somatotypes. Also, overall, anterior/posterior and medial/lateral dynamic balance scores were measured. Median (min-max) values of somatotypes at specified angular speeds and Kruskal-Wallis $\mathrm{H}$ test analysis results of knee isokinetic muscle strength $(\mathrm{Nm})$ at different angular speeds and overall, anterior/posterior and medial/lateral dynamic balance scores $(\mathrm{sec})$ in male and female participants are given below.

It was found that in male participants, mesomorph endomorph reached the highest score at left and right knee extension muscle strength at angular speeds of $90 \% \mathrm{sec}, 120 \% \mathrm{sec}, 150 \% \mathrm{sec}$, while balanced mesomorph somatotype reached the highest score at left and right knee flexion muscle strength at the same angular speeds. According to the KruskalWallis $\mathrm{H}$ test analysis, it was found that somatotype difference did not make a significant difference on dominant and non-dominant knee extension and flexion peak strength values at angular speeds of $90 \% \mathrm{sec}, 120 \% \mathrm{sec}, 15 \% \mathrm{sec}$ in male participants ( $>0.05)$. Endomorphic mesomorph somatotypes were found to reach the highest scores at overall, anterior/ posterior, and medial/lateral dynamic balance of male participants. According to the Kruskal-Wallis $\mathrm{H}$ test analysis conducted for different somatotypes and balance scores of male participants, no significant difference was found between males with different somatotypes and balance scores ( $p>0.05$ ), (Table 2).

It was found that in female participants, mesomorph endomorph somatotype reached the highest score at left and right knee extension muscle strength at angular speeds of $90 \% \mathrm{sec}$, $120 \% \mathrm{sec}, \quad 150 \% \mathrm{sec}$. Mesomorph endomorph somatotype at $90 \% \mathrm{sec}$ left knee flexion muscle strength, mesomorphic endomorph somatotype at $120 \% \mathrm{sec}$ left knee flexion muscle strength and endomorphic mesomorph somatotype at $150 \% \mathrm{sec}$ left knee flexion muscle strength were found to reach highest scores. Endomorphic mesomorph somatotype was found to reach the highest score at right knee extension muscle strength at angular speeds of $90 \% \mathrm{sec}, 120 \% \mathrm{sec}, 150 \% \mathrm{sec}$ in female participants. According to the Kruskal-Wallis H test analysis, it was found that somatotype difference did not make a significant difference on dominant and non-dominant knee extension and flexion peak strength values at angular speeds of $90 \% \mathrm{sec}$, $120 \% \mathrm{sec}, 150 \%$ sec in female participants ( $\mathrm{p}>0.05)$. Mesomorphic endomorph somatotypes were found to reach the highest scores at overall, anterior/ posterior and medial/lateral dynamic balance of female participants. According to the Kruskal-Wallis $\mathrm{H}$ test conducted for different somatotypes and balance scores of female participants, no significant difference was found between males with different somatotypes and balance scores $(\mathrm{p}>0.05)$, (Table 3 ).

\section{DISCUSSION}

Anthropometry technique can have significant contributions in determining a person's morphological and physiological state, determining employees fit for the job, learning the abilities of individuals who can start sports, and increasing their performances. In addition, anthropometry technique should not be ignored in maintaining a person's health and strength. ${ }^{[10,11]}$ Rienzi et al. ${ }^{[16]}$ reported that a player's capability profile was dependent on the kind of competition and his position in the game, which is directly related with the player's anthropometric measurements and somatotype scores. In the literature reviews, it can be seen that parameters which have inherited attributes such as height, weight, somatotype, and body composition influence skills and functional factors in sports branches.

One of the factors which affect performance are bodily structure, in other words, physical features, because bodily structure or physical features influence an individual's presenting his physiological capacities. Unless an individual's physical structure is suitable for the sports branch, it is not possible to reach the desired performance level. In the study of Lundy et al., ${ }^{[17]}$ the mean endomorphy component was $2.5 \pm 0.6$, while the mean mesomorphy component was $6.9 \pm 1.2$ and the mean ectomorphy component was $0.9 \pm 0.5$ in rugby players. In their studies, McArdle et al. ${ }^{[18]}$ and Toriola et al. ${ }^{[19]}$ also found significantly higher endomorphic and significantly lower mesomorphic scores in inactive individuals, while they found that athletes were mesomorphic ectomorph. Similarly, Bandyopadhyay ${ }^{[20]}$ found significantly higher mesomorphic scores in volleyball and football players, while ectomorphy component was significantly higher only in the volleyball group. Rienzi et al. ${ }^{[16]}$ found that South American international footballers were balanced mesomorph. While the somatotype of Russian elite footballers was reported as 1.7-5.6-2.6, the somatotype of their peers from Liverpool was 
reported as 2.4-4.2-2.4. ${ }^{[21,22]}$ Pazarözyurt ${ }^{[23]}$ reported endomorphy component in elite female basketball players as $2.24 \pm 0.69$, mesomorphy component as $2.7 \pm 1.26$, and ectomorphy component as $3.24 \pm 0.86$. In this study, the median endomorphy component was 3.9 (1.7-6.8), the median mesomorphy component was 5.5 (2.6-8.2), and the median ectomorphy component was $2.1(0.5-4.4)$ in male participants, while the median endomorphy component was 4.3 (3-7.4), the median mesomorphy component was 4 (2.5-7.1), and the median ectomorphy component $2.7(0.1-4.3)$ in female participants. This difference can be attributed to the fact that the participants in our study are not professional athletes.

Furthermore, in a study conducted with students of School of Physical Training and Sports, Bozlar ${ }^{[24]}$ found the somatotype components of the students as endomorphic mesomorph. Another study in Nigerian football players showed that $45 \%$ of mesomorph ectomorphs, $44 \%$ of mesomorphs, $85 \%$ of ectomorphs, and $50 \%$ of ectomorph mesomorphs had injuries. ${ }^{[25]}$ Therefore, the authors concluded that selecting football players according to their somatotype profiles might be helpful in reducing the injury rates, and mostly mesomorphs and mesomorph ectomorphs to a degree should be seen as football player candidates. In this study, the most frequent somatotype profile was endomorphic mesomorph in male participants, while it was mesomorph endomorph somatotype in female participants. Somatotypes of athletes vary according to technical and tactical demands conveyed to players and according to positional changes in different competition levels (i.e., local, national or international).

In an isokinetic knee muscle strength study, Tortop and $\mathrm{Ocak}^{[2]}$ included 30 athletes of different branches (age: $20.70 \pm 2.4$ years) and 30 controls (age: $20.87 \pm 2.4$ years), and found peak torque as $56.2 \pm 10.8 \mathrm{Nm}$ at dominant $60 \% \mathrm{sec}$ angular speed and as $60.0 \pm 10.7 \mathrm{Nm}$ at non-dominant $60 \% \mathrm{sec}$ angular speed, while they found peak torque as $66.7 \pm 11.5 \mathrm{Nm}$ at dominant $180 \% \mathrm{sec}$ angular speed and as $70.7 \pm 13.8 \mathrm{Nm}$ at non-dominant $180 \%$ sec angular speed. In their study, TournyChollet and Leroy ${ }^{[26]}$ showed that they were unable to find significant differences between the hamstring/ quadriceps $(\mathrm{H} / \mathrm{Q})$ rates of sedentary individuals and football players. However, Akin et al. ${ }^{[27]}$ found that the H/Q rate was statistically significantly higher in amateur football players, compared to professionals at angular speeds of $300 \% \mathrm{sec}$ and $450 \% \mathrm{sec}(\mathrm{p}<0.05)$. At an angular speed of $180 \% \mathrm{sec}$, the H/Q rates of amateur football players were found to be higher, compared to professional players, although this difference was not statistically significant $(\mathrm{p}>0.05)$. Beneka et al. ${ }^{[28]}$ reported that the H/Q rate, that is, extension-flexion rate, had to be $3 / 2$. Low $H / Q$ rates at different angular speeds of individuals who do sports, compared to the controls or sedentary individuals, can be seen, as athletes do unidirectional training and they show disproportional strength development. Higher peak strength rates of sedentary individuals who do not do sports and who are not athletes in the dominant limb suggest that sedentary individuals are not active in terms of sports. In other words, H/Q muscle groups have weaker structure in general and, since muscle groups are not specifically worked, no difference occurs between them in terms of muscular development. Therefore, close rates between strengths shows the result that peak strength rates are high. In many athlete trainings, knee extension muscle group is worked more and flexion muscle group is neglected. This state shows the result that the H/Q rates in athletes decrease more and may become an injury factor. While the H/Q rate shows muscular balance, it is also used as an indicator in preventing injuries. ${ }^{[2]}$ Yamamoto $^{[29]}$ reports that the imbalance between two muscle groups, particularly weak hamstring muscle, causes injuries. The H/Q peak strength rate is influenced by angular speed rather than age, sex, and dominant and nondominant features. As speed increases, the difference decreases. The rates have been reported as 50 to $60 \%$ at speeds of $30 \% \mathrm{sec}$ and $60 \% \mathrm{sec}$, as $60-70 \%$ at speeds of $120 \% \mathrm{sec}$ and $180 \% \mathrm{sec}$ and as $70-80 \%$ at speeds over $180^{\circ} .{ }^{[30]}$ In another study, the H/Q rates were found to be significantly lower in volleyball players, compared to football players. ${ }^{[1]}$ Different sport branches were found to influence isokinetic concentric H/Q rate. In another study conducted with other branch athletes, it was found that the H/Q rates increased, as the quality of athletes decreased. ${ }^{[1]}$ This finding is consistent with our results.

Dynamic balance is defined as the ability to keep stable position while performing. Dynamic balance is the required stability, while an athlete is reacting rapidly to the altered situations and moving, and the ability of balance has an important effect in an athlete's performance. When athletes are compared with nonathletes, it can be seen that athletes have a high ability of balance. ${ }^{[31]}$ Balance tests, which are the simulations of functional activities, are the most suitable test types to determine the contributions of musculoskeletal, vestibular and sight systems. As a result of the dynamic balance test they conducted on young adult university students, D'Andréa Greve et al. ${ }^{[32]}$ found that in male 
participants total balance scores were $6.6 \pm 2.8 \mathrm{sec}$, anterior/posterior balance scores were $4.9 \pm 2.0 \mathrm{sec}$, and medial lateral balance scores were $4.5 \pm 2.0 \mathrm{sec}$, while in female participants total balance scores were $3.3 \pm 2.7 \mathrm{sec}$, anterior/posterior balance scores were $2.9 \pm 2.0 \mathrm{sec}$ and medial lateral balance scores were $2.5 \pm 1.9 \mathrm{sec}$. These results show that females have better balance scores than males in all parameters (total balance, anterior/posterior balance, medial lateral balance). In their dynamic balance study conducted on football players and field hockey players, Bhat and $\mathrm{Moiz}^{[33]}$ did not find significant differences in all dimensions for all groups. Bressel et al. ${ }^{[31]}$ found that dynamic balance scores of university female basketball players and female gymnasts and football players were different. However, they did not find significant differences between football players and gymnasts. In their study, the mean dynamic balance score was $12.5 \pm 1.1 \mathrm{sec}$ in football players, $14.1 \pm 1.1 \mathrm{sec}$ in basketball players, and $9.1 \pm 1.1 \mathrm{sec}$ in gymnasts.

The main reason that there was no effect of somatotype difference on isokinetic knee muscle strength and balance tests was thought to be caused by the fact that all 146 participants included in the study were athletes. There are several studies which show that muscle strength and balance scores have high values in individuals who do sports all the time. ${ }^{[1,2]}$ In our study, since the participants had high muscle strength and balance ability, we found that somatotype difference did not have an evident effect on isokinetic muscle strength and balance scores.

In conclusion, conducting such studies at PTSS where many elite athletes are educated will be a resource for the future. When the participant students in the study become elites, their performances can be assessed according to their branches and physiological tests, and anthropometric measurements can be compared. Athletes who pass these tests may also contribute to further studies and athlete selections. Therefore, Turkey's position in elite sports competitions can reach higher levels, and individuals who wish to become athletes can be informed about which anthropometric measurements would be suitable in which sport branch.

\section{Declaration of conflicting interests}

The authors declared no conflicts of interest with respect to the authorship and/or publication of this article.

\section{Funding}

This research was supported by Inonu University BAP unit with project number 2014/27.

\section{REFERENCES}

1. Magalhães J, Oliveira J, Ascensão A, Soares J. Concentric quadriceps and hamstrings isokinetic strength in volleyball and soccer players. J Sports Med Phys Fitness 2004;44:119-25.

2. Tortop Y, Ocak Y. Elit düzey sporcularda diz eklemi hamstring/quadriceps (H/Q) izokinetik kuvvet oranlarının değerlendirilmesi. Nigde University Journal of Physical Education and Sport Sciences 2010;4:109-15.

3. Olyaei GR, Hadion MR, Talebian S, Bagheri H, Malmir $\mathrm{K}$, Olyaei $\mathrm{M}$. The effect of muscle fatigue on knee flexor to extensor torque ratios and knee dynamic stability. The Arabian Journal Of Science And Engineering 2006;31:121-7.

4. Miller LE, Pierson LM, Nickols-Richardson SM, Wootten DF, Selmon SE, Ramp WK, et al. Knee extensor and flexor torque development with concentric and eccentric isokinetic training. Res Q Exerc Sport 2006;77:58-63.

5. Zakas A, Galazoulas C, Doganis G, Zakas N. Effect of two acute static stretching durations of the rectus femoris muscle on quadriceps isokinetic peak torque in professional soccer players. Isokinetics and Exercise Science 2006;14:357-62.

6. Cobb SV. Measurement of postural stability before and after immersion in a virtual environment. Appl Ergon 1999;30:47-57.

7. Horak FB, Shupert CL, Mirka A. Components of postural dyscontrol in the elderly: a review. Neurobiol Aging 1989;10:727-38.

8. Ferdjallah M, Harris GF, Smith P, Wertsch JJ. Analysis of postural control synergies during quiet standing in healthy children and children with cerebral palsy. Clin Biomech (Bristol, Avon) 2002;17:203-10.

9. Kilınç F, Koç H, Erol AE, Pulur A, Gelen E. Kısa kamp döneminde uygulanan yoğun antrenmanların yıldız erkek basketbolcuların biyomotorik ve teknik performansları üzerine etkileri. Uluslararası İnsan Bilimleri Dergisi 2011;8:1071-81.

10. Norton K, Olds T. Anthropometrica: A textbook of body measurement for sports and health courses. SydneyAustralia: UNSW Press; 2004.

11. Akın, G, Tekdemir İ, Gültekin T, Erol E, Bektaş Y. Antropometri ve Spor. Ankara: Alter Yayınları; 2013.

12. Carling C, Le Gall F, Malina RM. Body size, skeletal maturity, and functional characteristics of elite academy soccer players on entry between 1992 and 2003. J Sports Sci 2012;30:1683-93.

13. Dias Quiterio AL, Carnero EA, Baptista FM, Sardinha LB. Skeletal mass in adolescent male athletes and nonathletes: relationships with high-impact sports. J Strength Cond Res 2011;25:3439-47.

14. Hewett TE, Myer GD, Ford KR. Decrease in neuromuscular control about the knee with maturation in female athletes. J Bone Joint Surg [Am] 2004;86:1601-8.

15. De Ste Croix M, Deighan M, Armstrong N. Functional eccentric-concentric ratio of knee extensors and flexors in pre-pubertal children, teenagers and adult males and females. Int J Sports Med 2007;28:768-72.

16. Rienzi E, Drust B, Reilly T, Carter JE, Martin A. Investigation of anthropometric and work-rate profiles of elite South American international soccer players. J Sports Med Phys Fitness 2000;40:162-9. 
17. Lundy B, O'Connor H, Pelly F, Caterson I. Anthropometric characteristics and competition dietary intakes of professional rugby league players. Int J Sport Nutr Exerc Metab 2006;16:199-213.

18. McArdle W, Katch FI, Katch VL. Exercise Physiology, Energy, Nutrition and Human Performance. Philadelphia: Lippincott Williams \& Wilkins; 2010.

19. Toriola AL, Salokun SO, Mathur DN. Somatotype characteristics of male sprinters, basketball, soccer, and field hockey players. Int J Sports Med 1985;6:344-6.

20. Bandyopadhyay A. Anthropometry and body composition in soccer and volleyball players in West Bengal, India. J Physiol Anthropol 2007;26:501-5.

21. Florida-James G, Reilly T. The physiological demands of Gaelic football. Br J Sports Med 1995;29:41-5.

22. Martirosov EG, Skomorokhov EV, Farmochi I, Varga Sh. Somatotypes of the world's leading young football players. Arkh Anat Gistol Embriol 1987;93:29-33. [Abstract]

23. Pazarözyurt İ. Elit bayan sporcularda antropometrik özellikler, dikey sıçrama ve omurga esnekliğinin mevkilere göre incelenmesi. [Yüksek Lisans Tezi], Adana: Sağlık Bilimleri Enstitüsü Beden Eğitimi ve Spor Anabilim Dalı; 2008.

24. Bozlar O. Beden eğitimi ve spor yüksek okulu öğrencilerinin antropometrik ve somatotip yapılarının incelenmesi. [Yüksek Lisans Tezi], Trabzon: Karadeniz Teknik Üniversitesi Beden Eğitimi ve Spor Yüksekokulu; 2011.

25. Salokun SO. Minimizing injury rates in soccer through preselection of players by somatotypes. J Sports Med Phys Fitness 1994;34:64-9.
26. Tourny-Chollet C. and Leroy D. “Conventional vs. Dynamic hamstring-quadriceps strength ratios". A comparison between players and sedentary subjects. Isokinetics Exer Sci 2002;10:183-92.

27. Akın S, Öner Ö, Özberk ZN, Ertan H, Korkusuz F. Profesyonel ve amatör futbol oyuncularının fiziksel özellikler ve izokinetik diz kaslarının konsantrik kuvvetinin karşılaştırması. Clinical Research 2004;15:161-7.

28. Beneka A, Malliou P, Ispirlidis I, Godolias G, Alexopoulos P. Restoration of Muscles Imbalances with a Spesific Strength Training. Program in young players. In: Book of Abstracts-5th World Congress on Science and Football. Faculty of Human Kinetcs Technical University of Lisbon; 2003. p. 88-9.

29. Yamamoto T. Relationship between hamstring strains and leg muscle strength. A follow-up study of collegiate track and field athletes. J Sports Med Phys Fitness 1993;33:194-9.

30. Perrin DH. Isokinetic Exercise and Assessment. Champaign: Human Kinetics Publishers; 1993.

31. Bressel E, Yonker JC, Kras J, Heath EM. Comparison of static and dynamic balance in female collegiate soccer, basketball, and gymnastics athletes. J Athl Train 2007;42:42-6.

32. D’Andréa Greve JM, Cuğ M, Dülgeroğlu D, Brech GC, Alonso AC. Relationship between anthropometric factors, gender, and balance under unstable conditions in young adults. Biomed Res Int 2013;2013:850424.

33. Bhat R, Moiz JA. Comparison of dynamic balance in collegiate field hockey and football players using star excursion balance test. Asian J Sports Med 2013;4:221-9. 